\title{
A Study on the Poverty of Mountain People Depending on Forests
}

\author{
Phuong Thi Minh NGUYEN', Song Van NGUYEN², Duc Tai DO ${ }^{3}$, Quynh Thi Thuy NGUYEN ${ }^{4}$, \\ Thanh Trung DINH ${ }^{5}$ Hang Phan Thu NGUYEN ${ }^{6}$
}

Received: May 13, 2020 Revised: May 24, 2020 Accepted: June 07, 2020

\begin{abstract}
Livelihood capitals have a clear influence on livelihood development. As for the livelihood results, it has been pointed out in the analysis of the poor households that the ability of people to escape poverty depends especially on the access to livelihood capitals. This study aims to analyze the impacts of livelihood capital on poverty among mountain people who depend on forests through human capital, social capital, natural capital, physical capital and financial capital. This research employs the model of binary regression function. Independent variables $\mathrm{x} 1, \mathrm{x} 2, \ldots, \mathrm{xn}$ are targets of livelihood strategy, vulnerability context, and livelihood capitals. These variables were selected to be included in the original model with dependent variable $\mathrm{Y}$ as poor and non-poor households. This study surveys households living in upland areas, near forests, and households of ethnic minorities. The results show that,out of the poor household rate, nearly $4 \%$ are newly-poor households or those falling back into poverty. Therefore, the government needs to pay more attention to this disadvantaged group and implements policies such as education and training policies, credit support policies, policies to support forest development, and payment for forest environmental services in the context of emerging countries like Vietnam.,
\end{abstract}

Keywords : Livelihood, Livelihood Captial, Poverty, Mountainous People, Vietnam

JEL Classification Code: I30, P36, P46, J15

\section{Introduction}

The livelihood approach is heavily used in rural development issues both in theory and practice (Scoones, 1998). The approach, viewpoints, methods, and development frameworks of livelihoods are heavily used in reports, analysis of development projects, and related studies. Sustainability is

${ }^{1}$ First Author and Corresponding Author. Lecturer, Department of Economics, Vinh University, Vietnam[Postal Address: No. 182, Le Duan Road, Vinh City, Nghe An Province, 113000, Vietnam] Email: phuongntm@vinhuni.edu.vn

${ }^{2}$ Professor, Vietnam National University of Agriculture. Email: nguyensonghua@gmail.com

${ }^{3}$ Lecturer, Department of Accounting, University of Labor and Social Affairs, Vietnam. Email: taiketoanquocte@gmail.com

${ }^{4}$ Lecturer, Department of Economics, Vinh University, Vietnam. Email: ntquynh83@gmail.com

${ }^{5}$ Associate Professor, Vinh University, Vietnam. Email: dinhtrungthanhdhv@gmail.com

6Lecturer, Sai Gon University, Vietnam. Email: npthuhang@yahoo.com

(c) Copyright: The Author(s)

This is an Open Access article distributed under the terms of the Creative Commons Attribution Non-Commercial License (http://Creativecommons.org/licenses/by-nc/4.0/) which permits unrestricted noncommercial use, distribution, and reproduction in any medium, provided the original work is properly cited. definitely the key to this approach as Chambers and Conway (1992) define the sustainable livelihoods. The perspectives on livelihood are formed by different individuals in different residential places. A variety of definitions is offered, for example, "the means of gaining a living" or "a combination of the resources used and the activities undertaken in order to live"(Chambers, 1995). According to this author, livelihood analysis is the description of a complex activity and interaction network, emphasizing the diversity of the ways that people make a living. The livelihood strategy includes a range of, and the combination of, activities and choices that individuals or households make to achieve livelihood goals (DFID, 1999). From there, the sustainable livelihood development strategy can be understood as the choice of people/households to achieve the increase in both quantity and quality in the direction of sustainability and stability in all three areas - economy, society, and environment.

Forest-dependent communities include: (i) poor communities and villages in remote, upland and border areas with large areas of land officially classified as protection forests; (ii) areas originally owned by the State Forest Enterprises or Watershed Management Board; (iii) communes and villages located within the boundaries or 
in areas of special use forests, national parks, and nature reserves; and (iv) communities depending on forest products in one way or another. Hence, the authors focus on groups of poor communities and villages in remote, highland, border areas who live near or in forested areas or regions with large areas of forest land. However, others define the dependence on production activities on the basis of household income structure. From that point, the level of dependence on income sources from agriculture (Xu et al., 2015), forests (Babulo et al., 2008), livestock (Alary et al., 2014; Douxchamps et al., 2015) are determined. As stated by Babulo et al. (2008), the dependence on forest is determined on the basis of forest income. Accordingly, the level of forest dependence is classified into three groups: high, medium, and low dependence on the forest.

It is necessary to make good use of livelihood capital and improve the livelihood capital efficiency for mountain households as livelihood capital is an important component of a sustainable livelihood framework (Chambers and Conway, 1992). In assessing the use of sustainable livelihood approach among agencies, Carney et al. (1999) concluded that all agencies, including DFID, FAO, CARE, the World Bank and Oxfam, adopted the approach based on household livelihood capitals. Livelihood capital consists of five groups, which are human, financial, physical, natural, and social capitals (DFID, 1999). These capitals are constantly changing. The sustainable livelihood development considers common capital trends in order to effectively exploit livelihood capitals for forest-dependent people. These capital sources combine a variety of ways to create positive livelihood development outcomes. Poverty and forests are often closely linked, in which most of forested areas with high coverage have a large number of poor people from upland ethnic minorities. Despite certain supportive policies to develop remote areas, they are still poor due to the difficulty in accessing the market, poor infrastructure, and poor soil. The poor often tend to focus on forest areas, as they do not have other opportunities to live in the crowded plains because of the difficulty in finding suitable livelihoods. The forest income of the poor and ethnic minorities is often higher than that of other groups (Iyenger and Shukla 1999). Based on a quantitative assessment of household income sources in the state of Uttar Pradesh in India, Reddy and Chakravarty (1999) found that household's forest income accounted for more than $22 \%$ of the total income. Therefore, poverty is considered as the main reason leading to deforestation and forest degradation. Household livelihood strategies are determined on the basis of dependence level on income sources such as agriculture (Xu et al., 2015), forests (Babulo et al., 2008), and livestock (Alary et al., 2014; Douxchamps et al., 2015).

Livelihood capital is an essential component of sustainable livelihood frameworks. Sustainable livelihood frameworks are all approaches based on the influence of livelihood capital. In the original definition of Chambers and Conway (1992) regarding sustainable livelihoods, it is only necessary to distinguish capital sources as tangible or intangible but then definitions of capital have been developed by different authors. In assessing the use of sustainable livelihood approach among agencies, Carney et al. (1999) concluded that all agencies, including DFID, FAO, CARE, the World Bank and Oxfam, adopted the approach based on household livelihood capitals.However, it should be noted that in the livelihood analysis framework, livelihood capital was slightly modified to use the same five capital types as used by other agencies. These types include human, natural, financial, physical, and social capitals. Capital formation 'is the main approach making fundamental changes to meet the basic needs of poor households (Hussein, 2002).Livelihood capitals have a clear influence on livelihood development. As for the livelihood results, it has been pointed out in the analysis of poor households that the ability of people to escape poverty depends especially on the access to livelihood capitals. Different capitals require different livelihood outcomes to be achieved. It can be seen that those with larger capitals will try to create more influence. Therefore, one way to achieve the sustainability in livelihood development is to support people by improving their livelihood capitals.

\section{Research Methodology}

Sustainable livelihood approaches seek to develop an understanding of factors behind people's livelihood strategy choices, then to reinforce positive aspects (factors motivating choice and flexibility) and minimize limitations or negative influences (Elliset al., 2003). The expansion of choices and values is crucial because it provides people with opportunities, determination and flexibility to adapt over time. It is a possibility that can be achieved by improving people's access to wealth, developing livelihood strategies and making structures and processes of transforming them become livelihood results as desired by peoples.

Previous studies have used different methods to develop livelihood strategies (Xu et al., 2015). Simply, they are divided into two groups - agriculturallydependent and non-agricultural ones (Fang et al., 2014). Some research groups use cluster analysis to categorize livelihood strategies into three or four different groups (Bhandari, 2013; Nguyen et al., 2015). However, others define livelihood strategies based on household income structure. From that point, household livelihood strategies is defined on the basis of dependence level on income such as agriculture (Xu et al., 2015), forest (Babulo et al., 2008), and livestock (Alary et al., 2014; Douxchamps et al., 2015). Besides, Mago (2014) attempts to bring together the empirical works that were done in different 
contexts to shed light on the important relationship between microfinance and poverty.Senadjki et al. (2017) examine the impact of risks and assets on households' vulnerability to poverty. The results indicated that risks are not a significant threat to households. Gender and strata are crucial elements that significantly determine households' vulnerability. While human capital and financial capital significantly reduce households' vulnerability to poverty, physical and natural capitals were not statistically significant. Kousar et al. (2019) used ARDL-Bounds testing approach for robust inferences. The results show that in the shortrun, remittances increase poverty and income inequality, which further translates into long-run impact. Pienkhuntodet al. (2020) examine the poverty indicators in the Northeast region of Thailand by adopting the global Multidimensional Poverty Index (MPI) methodology and the national survey of Minimum Basic Needs (MBN) of Thailand. The results show that poverty indicators in Khon Kaen province remain centered around the aspects of health and employment dimensions. While a change of family structure in the Thai society since 1960s led to a reduction in the family size, household savingssubstantially increased over the years. In this research, we use a forest-dependent approach. The forest income rate is used to classify livelihood strategies into three groups: low, medium, and high dependence.

Primary data were collected through direct interviews with semi-structured questionnaires with households living near forests, and group discussions focused on groups of households and local government officials. Each research site was located in upland villages/hamlets where households have the right to use forest land and access to forest resources. The research is conducted by direct interviews with 280 households living near forests. After collecting data, there were 15 incomplete questionnaires, so 265 households questionnaires were collected and processed. Primary data were aggregated and analyzed by Stata.

In order to evaluate the factors affecting the ability of households to fall into poor or non-poor groups, we used the model of binary regression function. Independent variables $\mathrm{x} 1, \mathrm{x} 2, \ldots, \mathrm{xn}$ are targets of livelihood strategy, vulnerability context, and livelihood capitals. These variables were selected to be included in the original model with dependent variable $\mathrm{Y}$ as poor and non-poor households. Applying the method of partial variable elimination, the research determined which significant variables to be included in the model.

This is a form of selected probability function, applying the maximum reasonable estimation method after the dependent variable, which is the probability ratio of poor and non-poor households, is put to the natural logarithm. The probability of falling into a poor household group of any household $\mathrm{i}$ is described as follows:

$$
P_{i}=E\left(Y=1 \mid X_{i}\right)=\frac{1}{1+e^{-\left(\beta_{0}+\beta_{i} X_{i}+u_{i}\right)}}
$$

$i=1,2,3 \ldots . n$ are the surveyed households; $Y=1$ for nonpoor households; $\mathrm{X}$ is the vector showing factors affecting the ability of non-poor households; $\beta$ is a vector showing the coefficient of independent variables' influence; $u_{i}$ is the random error. Setting $Z_{i}=\beta_{0}+\beta_{i} X+u_{i}$, if $P_{i}$ the probability of non-poor households, $\left(1-\mathrm{P}_{\mathrm{i}}\right)$ will be the probability of poor households and we have the following ratio:

$$
\frac{P_{i}}{1-P_{i}}=\frac{1+e^{Z_{i}}}{1+e^{-Z_{i}}}=e^{Z_{i}}
$$

This equation is called as the ratio of the probability of a poor and non-poor household. Using natural logarithms for this equation, the formula for the Logit, $\mathrm{L}(\mathrm{Y})$ model is obtained

$$
L\left(Y_{i}\right)=\ln \left(\frac{P_{i}}{1-P_{i}}\right)=Z_{i}=\beta_{0}+\beta_{i} X_{i}+u_{i}
$$

Targets measuring human capital include: (i) household size on the basis of measuring the number of people in a household; (ii) the number of working people in a household; (iii) educational level of the householder classified as one of the following groups: those who have not completed primary school, completed primary school, completed secondary school, and high school or higher; (iv) sex of the householder (male/female); (v) age of the householder (years); (vi) average age of household members (years); (vii) level of participation in local training classes (hardly/occasionally/ usually).

Social capital is explored through village/hanmlet regulations conventions, social relationships of the community and households. Specific quantitative targets include: (i) frequency of being invited to local training classes (hardly/occasionally/usually); (ii) participation in forest patrol teams (yes/no); (iii) trust of local people (yes/ no); and (iv) ability to get help when needed (rare/possible/ available).

Natural capital is considered on the basis of the land area owned by the household and the access to public services/ assets. Specifically, they include: (i) area of agricultural land, forests, other land, and total household land area; (ii) access to forest resources based on understanding distance from household to forest by distance $(\mathrm{km})$ and time (minutes); (iii) distance to commune center (km); (iv) distance to local market (km); and (v) access to clean water sources (yes/no). 
Physical capital is measured by the condition of household's houses and asset. In this research, specific research targets include: (i) the actual situation of household's specific assets; (ii) housing status of the household; and (iii) housing quality of the household.

Financial capital is determined by five target groups including: (i) the level of meeting minimum needs of the household (significantly insufficient/slightly insufficient/ sufficient); (ii) number of household income sources (less than 4 sources/4 sources/5 sources); (iii) households with working people having stable incomes (yes/no); (iv) whether the household has savings (yes/no); and (v) whether the household owes debts (yes/no).

Data analysis methods include descriptive statistical methods, comparative methods combined with statistical testing tools such as T-test, Chi square, Anova analysis. In order to evaluate the impacts of these factors, the research uses econometric functions, including multivariate regression, binary functions, and hierarchical logarithmic functions.

\section{Research Results}

In the part, human capital, social capital, natural capital, physical capital, financial capital are analyzed below:

\subsection{Human Capital}

The average household size in the survey area is 4.65 people, of which the number of members at working age accounts for $66.24 \%$ (3.08 members). This shows that Vietnam has a plentiful labor force and a great development potential. Various studies indicate that large-scale households with high labor rates bring strong human capital to them. Results of this research also show the same conclusion when the test results show that poor households are usually smallscale households with only 4.15 members (lower than 4.92 of non-poor households), and $63.37 \%$ of people at working age - nearly $5 \%$ lower than that of non-poor households (see Table 1).

\subsection{Social Capital}

The trust of local people in the community is considerably high, and there is no difference between the poor and nonpoor household groups as well as the forest high and low dependent household groups. However, the difference from being trusted to getting help when needed is different. Test results show that the group of households in upland and forest areas as well as poor households finds it more difficultly to seek assistance from friends or neighbors when facing difficulties than the remaining groups, especially regarding material assistance (see Table 2).

\subsection{Natural Capital}

The total average landholding area of households is 4.05 ha/household, of which the majority is forestry land (3.45 ha/household), land for husbandry and aquaculture is 0.5 ha/household. Housing land and mixed garden associated with residential land accounts on average for about 1000 $\mathrm{m} 2$ /household. The total land area owned by households is no different in statistical significance between the poor and non-poor household groups. This is considerably different from other research that points out that the owned land area has a significant and clear influence on household income. Nonetheless, in this study, this impact is not clear because the land area owned by the householder is forestry land, which has not brought much income due to difficult transportation. Like the results of other research, the agricultural land area has a statistically significant difference between poor and non-poor household groups. Poor households often own smaller land areas (see Table 3).

\subsection{Physical Capital}

The housing status of household groups classified by forest dependency also has a statistically significant difference. Results show that the higher the level of dependency on the forest, the lower the housing status. The ratio of households classified as those having solid and permanent houses is $30.14 \%, 37.5 \%$ and $53.57 \%$ for households with high, medium and low dependency on forests, respectively. However, test results on the housing quality do not indicate any statistically significant differences (see Table 4).

\subsection{Financial Capital}

The census sample focuses on households living near forests, upland areas, mainly ethnic minorities, with a high proportion of poor households. Therefore, as an average of the entire census sample, only $38 \%$ of households have income to meet their first-necessity needs. The level of savings is very low $(11.32 \%)$, which is mainly savings on the basis of procurement of production tools, savings in cash or credit institutions are almost nonexistent. The indebtedness of the people is very high $(76.6 \%)$ with the fact that they have to owe agricultural supplies shops for their livelihood activities. Financial endowment disparities between household groups are clear with high reliability (99\%) (see Table 5).

\section{Discussion}

The results of estimating the binary model (Binary) using Stata 12.0 software are presented in the above table showing that the Wald chi 2 test value $=56.46$ is statistically significant at $1 \%$, proving the conformity of the model. We 
Phuong Thi Minh NGUYEN, Song Van NGUYEN, Duc Tai DO, Quynh Thi Thuy NGUYEN, Thanh Trung DINH, Hang Phan Thu NGUYEN $/$

Table 1: Human capital of households

\begin{tabular}{|c|c|c|c|c|c|c|}
\hline & \multirow[t]{2}{*}{ Target } & \multirow{2}{*}{ Unit } & \multicolumn{3}{|c|}{$\begin{array}{l}\text { Livelihood strategies by forest } \\
\text { dependency level }\end{array}$} & \multirow{2}{*}{ Overall } \\
\hline & & & Medium & Low & High & \\
\hline \multirow{3}{*}{$\begin{array}{l}\text { The number } \\
\text { of people in a } \\
\text { household }\end{array}$} & TB & $\begin{array}{c}\text { people/ } \\
\text { household }\end{array}$ & 4.63 & 4.49 & 4.77 & 4.65 \\
\hline & SD & $\begin{array}{c}\text { people/ } \\
\text { household }\end{array}$ & 1.37 & 1.37 & 1.50 & 1.43 \\
\hline & \multicolumn{2}{|l|}{$P$ test } & \multicolumn{3}{|c|}{0.405} & \\
\hline \multirow{3}{*}{$\begin{array}{l}\text { The number of } \\
\text { working people }\end{array}$} & TB & $\begin{array}{l}\text { People/ } \\
\text { household }\end{array}$ & 2.99 & 2.98 & 3.22 & 3.08 \\
\hline & SD & $\begin{array}{c}\text { Working } \\
\text { people/ } \\
\text { household }\end{array}$ & 1.11 & 1.14 & 1.28 & 1.19 \\
\hline & \multicolumn{2}{|l|}{$P$ test } & \multicolumn{3}{|c|}{0.263} & \\
\hline \multirow{5}{*}{$\begin{array}{l}\text { Level of the } \\
\text { householder }\end{array}$} & $\begin{array}{l}\text { Not completed primary } \\
\text { school }\end{array}$ & $\%$ & 10.96 & 8.75 & 2.68 & 6.79 \\
\hline & $\begin{array}{c}\text { Completed primary } \\
\text { school }\end{array}$ & $\%$ & 46.58 & 41.25 & 20.54 & 33.96 \\
\hline & $\begin{array}{l}\text { Completed secondary } \\
\text { school }\end{array}$ & $\%$ & 34.25 & 27.50 & 41.07 & 35.09 \\
\hline & High school and higher & $\%$ & 8.22 & 22.50 & 35.71 & 24.15 \\
\hline & \multicolumn{2}{|l|}{ (p) Test $x^{2}$} & \multicolumn{3}{|c|}{0.000} & \\
\hline \multirow{3}{*}{$\begin{array}{l}\text { Sex of the } \\
\text { householder }\end{array}$} & Male & $\%$ & 93.15 & 93.75 & 95.54 & 94.34 \\
\hline & Female & $\%$ & 6.85 & 6.25 & 4.46 & 5.66 \\
\hline & \multicolumn{2}{|l|}{ (p) test $x^{2}$} & \multicolumn{3}{|c|}{0.0761} & \\
\hline \multirow{3}{*}{$\begin{array}{l}\text { Age of the } \\
\text { householder }\end{array}$} & TB & Year & 46.96 & 43.70 & 42.53 & 44.10 \\
\hline & SD & Year & 10.65 & 10.57 & 10.24 & 10.57 \\
\hline & \multicolumn{2}{|l|}{$P$ test } & \multicolumn{3}{|c|}{0.018} & \\
\hline \multirow{3}{*}{$\begin{array}{l}\text { Average age of } \\
\text { members }\end{array}$} & TB & Year & 28.74 & 27.26 & 27.52 & 27.77 \\
\hline & SD & Year & 9.64 & 9.08 & 10.36 & 9.77 \\
\hline & \multicolumn{2}{|l|}{$P$ test } & \multicolumn{3}{|c|}{0.604} & \\
\hline \multirow{4}{*}{$\begin{array}{l}\text { Participation in } \\
\text { the training class }\end{array}$} & Hardly & $\%$ & 21.92 & 13.75 & 14.29 & 16.23 \\
\hline & Occasionally & $\%$ & 8.22 & 17.50 & 13.39 & 13.21 \\
\hline & Usually & $\%$ & 69.86 & 68.75 & 72.32 & 70.57 \\
\hline & \multicolumn{2}{|l|}{ (p) Test $x^{2}$} & \multicolumn{3}{|c|}{0.330} & \\
\hline
\end{tabular}


Table 2: Social capital of households (\%)

\begin{tabular}{|c|c|c|c|c|c|c|}
\hline \multirow{2}{*}{\multicolumn{2}{|c|}{ Target }} & \multirow{3}{*}{$\begin{array}{c}\text { Unit } \\
\%\end{array}$} & \multicolumn{3}{|c|}{$\begin{array}{l}\text { Livelihood strategies by forest } \\
\text { dependency level }\end{array}$} & \multirow[t]{2}{*}{ Overall } \\
\hline & & & Medium & Low & High & \\
\hline \multirow{3}{*}{$\begin{array}{l}\text { Regular participation in activities } \\
\text { of local organizations }\end{array}$} & Yes & & 72.60 & 81.25 & 84.82 & 80.38 \\
\hline & No & $\%$ & 27.40 & 18.75 & 15.18 & 19.61 \\
\hline & \multicolumn{2}{|c|}{ (p) Test $x^{2}$} & \multicolumn{3}{|c|}{0.121} & \\
\hline \multirow{3}{*}{$\begin{array}{l}\text { Regular participation in village } \\
\text { meetings }\end{array}$} & Yes & $\%$ & 93.15 & 97.50 & 97.32 & 96.23 \\
\hline & No & $\%$ & 6.85 & 3.50 & 3.68 & 3.77 \\
\hline & \multicolumn{2}{|c|}{ (p) Test $x^{2}$} & \multicolumn{3}{|c|}{0.271} & \\
\hline \multirow{4}{*}{$\begin{array}{l}\text { Frequency of being invited to } \\
\text { attend the training class }\end{array}$} & Hardly & $\%$ & 39.73 & 26.25 & 23.21 & 28.68 \\
\hline & Occasionally & $\%$ & 20.55 & 25.00 & 25.00 & 23.77 \\
\hline & Usually & $\%$ & 39.73 & 48.75 & 51.79 & 47.55 \\
\hline & \multicolumn{2}{|c|}{ (p) Test $x^{2}$} & \multicolumn{3}{|c|}{0.180} & \\
\hline \multirow{3}{*}{$\begin{array}{l}\text { Participation in forest patrol } \\
\text { teams }\end{array}$} & Yes & $\%$ & 67.12 & 55.00 & 47.32 & 55.09 \\
\hline & No & $\%$ & 32.88 & 45.00 & 52.68 & 44.91 \\
\hline & \multicolumn{2}{|c|}{ (p) Test $x^{2}$} & \multicolumn{3}{|c|}{0.030} & \\
\hline \multirow{3}{*}{ Trust of local people } & Yes & $\%$ & 79.45 & 85.00 & 86.61 & 84.15 \\
\hline & No & $\%$ & 20.55 & 15.00 & 13.39 & 15.85 \\
\hline & \multicolumn{2}{|c|}{ (p) Test $x^{2}$} & \multicolumn{3}{|c|}{0.415} & \\
\hline \multirow{4}{*}{ Ability to get help when needed } & Rare & $\%$ & 12.33 & 3.75 & 3.57 & 6.04 \\
\hline & Possible & $\%$ & 24.66 & 16.25 & 9.82 & 15.85 \\
\hline & Available & $\%$ & 63.01 & 80.00 & 85.71 & 77.74 \\
\hline & \multicolumn{2}{|c|}{ (p) Test $x^{2}$} & \multicolumn{3}{|c|}{0.003} & \\
\hline
\end{tabular}

Table 3: Natural capital of households

\begin{tabular}{|c|c|c|c|c|c|c|}
\hline \multirow{2}{*}{\multicolumn{2}{|c|}{ Target }} & \multirow{3}{*}{$\begin{array}{c}\text { Unit } \\
\text { ha }\end{array}$} & \multicolumn{3}{|c|}{ Livelihood strategies by forest dependency level } & \multirow{2}{*}{ Overall } \\
\hline & & & Medium & Low & High & \\
\hline \multirow{3}{*}{ Agricultural land area } & TB & & 0.50 & 0.48 & 0.53 & 0.51 \\
\hline & SD & ha & 0.32 & 0.26 & 0.29 & 0.29 \\
\hline & \multicolumn{2}{|c|}{$\mathrm{P}$ test } & \multicolumn{3}{|c|}{0.571} & \\
\hline \multirow{3}{*}{ Forestry land area } & TB & ha & 2.11 & 1.60 & 5.64 & 3.45 \\
\hline & SD & ha & 6.65 & 2.90 & 10.13 & 7.83 \\
\hline & \multicolumn{2}{|c|}{$\mathrm{P}$ test } & \multicolumn{3}{|c|}{0.000} & \\
\hline \multirow{3}{*}{ Other land area } & TB & ha & 0.05 & 0.06 & 0.15 & 0.10 \\
\hline & SD & ha & 0.06 & 0.08 & 0.50 & 0.33 \\
\hline & \multicolumn{2}{|c|}{$\mathrm{P}$ test } & \multicolumn{3}{|c|}{0.078} & \\
\hline \multirow{3}{*}{ Total land area } & TB & ha & 2.66 & 2.15 & 6.32 & 4.05 \\
\hline & SD & ha & 6.59 & 2.95 & 10.17 & 7.86 \\
\hline & \multicolumn{2}{|c|}{$\mathrm{P}$ test } & \multicolumn{3}{|c|}{0.000} & \\
\hline \multirow{3}{*}{$\begin{array}{l}\text { Distance from the household } \\
\text { to forest }\end{array}$} & TB & $\mathrm{km}$ & 1.13 & 1.04 & 1.14 & 1.11 \\
\hline & $\mathrm{SD}$ & $\mathrm{km}$ & 1.26 & 1.17 & 1.36 & 1.27 \\
\hline & \multicolumn{2}{|c|}{$\mathrm{P}$ test } & \multicolumn{3}{|c|}{0.867} & \\
\hline \multirow{3}{*}{$\begin{array}{l}\text { Duration from the household } \\
\text { to forest }\end{array}$} & TB & $\min$ & 19.66 & 20.06 & 22.23 & 20.87 \\
\hline & SD & $\min$ & 26.20 & 22.93 & 34.91 & 29.29 \\
\hline & \multicolumn{2}{|c|}{$\mathrm{P}$ test } & \multicolumn{3}{|c|}{0.808} & \\
\hline \multirow{3}{*}{$\begin{array}{l}\text { Distance from the household } \\
\text { to commune center }\end{array}$} & TB & $\mathrm{km}$ & 3.92 & 3.70 & 3.57 & 3.71 \\
\hline & SD & $\mathrm{km}$ & 1.24 & 1.07 & 1.46 & 1.30 \\
\hline & \multicolumn{2}{|c|}{ P test } & \multicolumn{3}{|c|}{0.208} & \\
\hline \multirow{3}{*}{$\begin{array}{l}\text { Distance from the household } \\
\text { to local market }\end{array}$} & TB & $\mathrm{km}$ & 7.92 & 10.73 & 9.46 & 9.42 \\
\hline & SD & $\mathrm{km}$ & 5.01 & 6.10 & 6.63 & 6.13 \\
\hline & \multicolumn{2}{|c|}{$\mathrm{P}$ test } & \multicolumn{3}{|c|}{0.018} & \\
\hline \multirow{3}{*}{$\begin{array}{l}\text { Ratio of households having } \\
\text { access to hygienic water }\end{array}$} & TB & $\%$ & 0.75 & 0.61 & 0.62 & 0.65 \\
\hline & SD & $\%$ & 0.43 & 0.49 & 0.49 & 0.48 \\
\hline & \multicolumn{2}{|c|}{$\mathrm{P}$ test } & \multicolumn{3}{|c|}{0.106} & \\
\hline
\end{tabular}


Phuong Thi Minh NGUYEN, Song Van NGUYEN, Duc Tai DO, Quynh Thi Thuy NGUYEN, Thanh Trung DINH, Hang Phan Thu NGUYEN $/$

Table 4: Physical capital of households

\begin{tabular}{|c|c|c|c|c|c|c|}
\hline \multirow{2}{*}{\multicolumn{2}{|c|}{ Target }} & \multirow{3}{*}{$\begin{array}{l}\text { Unit } \\
\%\end{array}$} & \multicolumn{3}{|c|}{$\begin{array}{c}\text { Livelihood strategies by forest } \\
\text { dependency level }\end{array}$} & \multirow{3}{*}{$\begin{array}{l}\text { Overall } \\
42.26\end{array}$} \\
\hline & & & Medium & Low & High & \\
\hline \multirow{4}{*}{ Housing status } & Permanent & & 30.14 & 37.50 & 53.57 & \\
\hline & Semi-permanent & $\%$ & 68.49 & 55.00 & 42.86 & 53.58 \\
\hline & Temporary & $\%$ & 1.37 & 7.50 & 3.57 & 4.15 \\
\hline & \multicolumn{2}{|l|}{ (p) Test $X^{2}$} & \multicolumn{3}{|c|}{0.004} & \\
\hline \multirow{4}{*}{ Housing quality } & High & $\%$ & 13.70 & 12.50 & 19.64 & 15.85 \\
\hline & Acceptable & $\%$ & 76.71 & 78.75 & 69.64 & 74.34 \\
\hline & Low & $\%$ & 9.59 & 8.75 & 10.71 & 9.81 \\
\hline & \multicolumn{2}{|l|}{ (p) Test $x^{2}$} & \multicolumn{3}{|c|}{0.630} & \\
\hline \multirow{3}{*}{ Living asset points } & TB & Point & 22.97 & 26.64 & 38.30 & 30.56 \\
\hline & SD & Point & 13.56 & 16.00 & 27.19 & 21.99 \\
\hline & \multicolumn{2}{|l|}{$P$ test } & \multicolumn{3}{|c|}{0.000} & \\
\hline \multirow{3}{*}{$\begin{array}{l}\text { Business and } \\
\text { production points }\end{array}$} & TB & Point & 14.49 & 16.20 & 19.16 & 16.98 \\
\hline & SD & Point & 8.98 & 8.97 & 12.20 & 10.61 \\
\hline & \multicolumn{2}{|l|}{$\mathrm{P}$ test } & \multicolumn{3}{|c|}{0.010} & \\
\hline
\end{tabular}

Table 5: Financial endowment of the household (\%)

\begin{tabular}{|c|c|c|c|c|c|}
\hline & \multirow[t]{2}{*}{ Target } & \multicolumn{3}{|c|}{$\begin{array}{l}\text { Livelihood strategies by forest dependency } \\
\text { level }\end{array}$} & \multirow[t]{2}{*}{ Overall } \\
\hline & & Medium & Low & High & \\
\hline \multirow{4}{*}{$\begin{array}{l}\text { The level of meeting the } \\
\text { minimum needs of the } \\
\text { household }\end{array}$} & Serious lack & 35.62 & 26.25 & 19.64 & 26.04 \\
\hline & Inconsiderable lack & 42.47 & 42.50 & 27.68 & 36.23 \\
\hline & Sufficiency & 21.92 & 31.25 & 52.68 & 37.74 \\
\hline & (p) Test $x^{2}$ & \multicolumn{3}{|c|}{0.000} & \\
\hline \multirow{4}{*}{$\begin{array}{l}\text { Number of income } \\
\text { sources for the } \\
\text { household }\end{array}$} & Less than 4 sources & 72.60 & 50.00 & 27.68 & 46.79 \\
\hline & 4 sources & 20.55 & 38.75 & 44.64 & 36.23 \\
\hline & 5 sources & 6.85 & 11.25 & 27.68 & 16.98 \\
\hline & (p) Test $X^{2}$ & \multicolumn{3}{|c|}{0.000} & \\
\hline \multirow{3}{*}{$\begin{array}{l}\text { The proportion of } \\
\text { households with } \\
\text { employees with stable } \\
\text { incomes }\end{array}$} & TB & 5.48 & 18.75 & 48.21 & 27.55 \\
\hline & SD & 22.92 & 39.28 & 50.19 & 44.76 \\
\hline & $\mathrm{P}$ test & \multicolumn{3}{|c|}{0.000} & \\
\hline \multirow{3}{*}{$\begin{array}{l}\text { Proportion of } \\
\text { households with savings }\end{array}$} & TB & 2.74 & 8.75 & 18.75 & 11.32 \\
\hline & SD & 16.44 & 28.43 & 39.21 & 31.74 \\
\hline & $\mathrm{P}$ test & \multicolumn{3}{|c|}{0.002} & \\
\hline \multirow{3}{*}{$\begin{array}{l}\text { Proportion of } \\
\text { households in debt }\end{array}$} & TB & 68.49 & 81.25 & 78.57 & 76.60 \\
\hline & SD & 46.78 & 39.28 & 41.22 & 42.41 \\
\hline & $\mathrm{P}$ test & \multicolumn{3}{|c|}{0.145} & \\
\hline
\end{tabular}


did not detect multicollinearity of independent variables in the study data. In addition, z-test values and robust standard errors are used to avoid heteroscedasticity.The results show that, there are 13 estimated parameters that are considered to have statistical significance and explain more than $55 \%$ of the poverty of the research households (see Table 6).

The estimated coefficient of the forest-dependent variable is positive and statistically significant at $10 \%$ and $5 \%$. This shows that the higher the household's dependence on the forest, the more likely it is that the household will fall into the groups of poor households. This result is consistent with the results of testing and analyzing the impact of the level of forest dependence on household income in the previous section. This once again confirms that the State should have policies to reduce household dependence on forests, and should not encourage the exploitation and use of forest resources for upland communities. Solutions to support non-forestry career development such as cultivation and husbandry are necessary.

Regarding financial capital, the two indicators of savings and employee with stable income have a statistically significant effect on the household's poverty status. This effect is in the same direction and, accordingly, households with savings and households with employee having stable income are important factors for households to join the group of non-poor households. If at least one member of the household has a stable job, it will help the household increase the chance of escaping poverty by $13 \%$. Therefore, the State and local governments need to implement specific solutions to maintain and promote the national target program on employment and vocational training. In the period of 20112015 , this national target program only disbursed $44 \%$ of the total approved budget - this is a huge limitation that the next phase needs to be improved.

Among the three research indicators of human capital, only the educational attainment of the householder has a clear impact on household poverty. The influence of other indicators is not clear. The direction of the impact on the educational attainment variable of the householder is also consistent with the household's poverty status. In other words, the higher the educational attainment of the householder, the higher the probability of a household escaping poverty from $9.9 \%-15.5 \%$. The householder has a decisive role in the livelihood activities of his/her family. Whether or not a household's livelihood is good depends on the quality of the decision. Many studies show that the level of decision-makers has a great influence on the quality of decisions being made. Therefore, the results of this research are similar to other studies when confirming the influence of the householder on the poverty status of the household.

Endowment of natural capital also shows a clear influence on the poverty status of households in the study area. Like many other studies, agricultural land area is an important condition in poverty reduction. The marginal impact coefficient at the average point shows that if the household's agricultural land area increases by $100 \%$, it will help the household increase by $11.7 \%$ the possibility of escaping poverty. However, the ability to increase agricultural land area for households is quite limited due to limited land area. The study area only has a small percentage of unused land. Therefore, solutions to increase land use coefficients should be applied, in addition to applying scientific and technical advances, advanced farming methods and improving plant varieties for high economic efficiency. Another indicator of the natural capital endowment group that has a statistically significant impact on household poverty is the variable of the distance from the household to the local market. Other studies often show that the shorter the distance, the better the household's livelihoods will be, thereby helping to escape poverty. However, the results of this research indicate otherwise. The negative coefficient of the binary function implies that the closer the households are to the local market, the poorer they are. This is not too difficult to explain in the study area. At the local market, households mainly come to buy necessities for daily life, very few households use the market for selling harvested agricultural products. In addition, the very low marginal impact coefficient $(-0.013)$ also shows the very small impact of this variable on household poverty in Vietnam.

All indicators including housing status, living assets, and production assets of the material capital endowment used in the research binary model are statistically significant with 99\% reliability. Like other capital endowments, material capital endowment indicators have an impact in the same direction on household poverty in the study area. For the household housing condition variable, if the household has a poor housing condition (temporary house), the probability of a household in the non-poor group is $8.1 \%$ lower than that of a semi-permanent house. However, compared to households with permanent houses, the direction of impact on poverty is significant but the marginal impact coefficient at the mean is not clear. The scores of production and living assets have a clear impact from the impact direction to the marginal impact coefficient. The value of the coefficient is quite large, at $14.6 \%$ and $10.9 \%$, respectively, indicating that these are two important variables affecting the poverty of the household. This implies that, if the household improves its assets, including production and living assets, it will improve the probability of falling into the poor group.

Social capital and poverty status of the household also have a positive relationship. The result of social capital is shown by the fact that households are invited to participate in local forest patrol and training courses. Households who are invited to participate in training courses will be given the opportunity to participate and thereby improve their 
Phuong Thi Minh NGUYEN, Song Van NGUYEN, Duc Tai DO, Quynh Thi Thuy NGUYEN, Thanh Trung DINH, Hang Phan Thu NGUYEN /

Table 6: Estimated results of the binary function on the factors affecting household poverty

\begin{tabular}{|c|c|c|c|c|c|c|c|}
\hline \multirow[b]{2}{*}{$\begin{array}{l}\text { Name of independent } \\
\text { variable }\end{array}$} & \multicolumn{4}{|c|}{ Estimated value } & \multicolumn{3}{|c|}{ Marginal impact value } \\
\hline & & Coefficient & $\begin{array}{l}\text { Robust } \\
\text { Std. Err. }\end{array}$ & $P>Z$ & dy/dx & $\begin{array}{l}\text { Delta- } \\
\text { method } \\
\text { Std. Err. }\end{array}$ & $P>Z$ \\
\hline \multirow{3}{*}{ PTVR level } & High & $1.852^{* *}$ & 0.892 & 0.038 & $0.121^{* *}$ & 0.054 & 0.024 \\
\hline & Medium & $1.104^{*}$ & 0.689 & 0.100 & $0.093^{*}$ & 0.057 & 0.100 \\
\hline & Low $_{\text {bs }}$ & & & & & & \\
\hline \multicolumn{2}{|c|}{$\begin{array}{l}\text { Households are significantly affected by the } \\
\text { vulnerability context }{ }^{d}\end{array}$} & $0.838^{\mathrm{NS}}$ & 0.593 & 0.157 & $0.049^{N S}$ & 0.034 & 0.152 \\
\hline \multicolumn{2}{|c|}{ Households have savings $^{d}$} & $4.288^{*+* * t}$ & 1.139 & 0.000 & $0.114^{* * *}$ & 0.047 & 0.016 \\
\hline \multicolumn{2}{|c|}{ Households are currently in debt ${ }^{d}$} & $-0.955^{\mathrm{NS}}$ & 0.711 & 0.179 & $-0.051^{\mathrm{NS}}$ & 0.035 & 0.141 \\
\hline \multicolumn{2}{|c|}{$\begin{array}{l}\text { Households with employees having stable } \\
\text { incomes }{ }^{d}\end{array}$} & $2.572^{* * *}$ & 0.842 & 0.002 & $0.130^{* * *}$ & 0.046 & 0.005 \\
\hline \multicolumn{2}{|c|}{ Number of employees in the household } & $-0.366^{\mathrm{NS}}$ & 0.700 & 0.601 & $-0.024^{\mathrm{NS}}$ & 0.044 & 0.583 \\
\hline \multirow{4}{*}{$\begin{array}{l}\text { Educational } \\
\text { attainment of the } \\
\text { householder }\end{array}$} & $\begin{array}{l}\text { Not completed } \\
\text { primary school }\end{array}$ & $-1.516^{*}$ & 0.909 & 0.096 & $-0.130^{\star *}$ & 0.058 & 0.025 \\
\hline & $\begin{array}{l}\text { Completed primary } \\
\text { school bcs }\end{array}$ & & & & & & \\
\hline & $\begin{array}{c}\text { Completed } \\
\text { secondary school }\end{array}$ & $0.956^{*}$ & 0.574 & 0.096 & $0.099^{*}$ & 0.058 & 0.090 \\
\hline & Higher & $2.424^{* *}$ & 1.174 & 0.039 & $0.155^{\text {tat }}$ & 0.057 & 0.006 \\
\hline \multicolumn{2}{|c|}{ Age of householder (year) ${ }^{\log }$} & $0.736^{\mathrm{NS}}$ & 0.721 & 0.308 & $0.048^{\mathrm{NS}}$ & 0.048 & 0.313 \\
\hline \multicolumn{2}{|c|}{ Agricultural land area (ha) ${ }^{\log }$} & $1.788^{*+*+}$ & 0.648 & 0.006 & $0.117^{* *}$ & 0.046 & 0.011 \\
\hline \multicolumn{2}{|l|}{ Forest land area (ha) ${ }^{\text {log }}$} & $-0.271^{\mathrm{NS}}$ & 0.179 & 0.131 & $-0.018^{\mathrm{NS}}$ & 0.014 & 0.199 \\
\hline \multicolumn{2}{|c|}{$\begin{array}{l}\text { Households have access to guaranteed } \\
\text { water }^{d}\end{array}$} & $-0.646^{\mathrm{NS}}$ & 0.877 & 0.461 & $-0.040^{\mathrm{NS}}$ & 0.056 & 0.478 \\
\hline \multicolumn{2}{|c|}{ Households near the market $^{d}$} & $-0.194^{* *}$ & 0.092 & 0.035 & $-0.013^{*}$ & 0.007 & 0.058 \\
\hline \multirow{3}{*}{$\begin{array}{l}\text { Housing quality of the } \\
\text { household }\end{array}$} & Temporary bcs & & & & & & \\
\hline & Semi-permanent & $-3.107^{* * * x}$ & 1.125 & 0.006 & $-0.205^{\mathrm{NS}}$ & 0.189 & 0.277 \\
\hline & Permanent & $-2.110^{*+*}$ & 0.685 & 0.002 & $-0.081^{* *}$ & 0.037 & 0.028 \\
\hline \multicolumn{2}{|l|}{ Living property ${ }^{\log }$} & $2.228^{*+*+}$ & 0.624 & 0.000 & $0.146^{* *}$ & 0.063 & 0.021 \\
\hline \multicolumn{2}{|l|}{ Production propertylog } & $1.666^{*+*}$ & 0.594 & 0.005 & $0.109^{*+* x}$ & 0.036 & 0.002 \\
\hline \multirow{3}{*}{$\begin{array}{l}\text { Households are } \\
\text { invited to participate in } \\
\text { the training }\end{array}$} & Regularly bcs & & & & & & \\
\hline & Normal & $1.331^{*}$ & 0.790 & 0.092 & $0.097^{*}$ & 0.059 & 0.097 \\
\hline & Sometimes & $0.851^{\mathrm{NS}}$ & 0.654 & 0.193 & $0.074^{\mathrm{NS}}$ & 0.060 & 0.216 \\
\hline \multicolumn{2}{|c|}{$\begin{array}{l}\text { Households participate in forest patrol } \\
\text { teams }{ }^{d}\end{array}$} & $-2.168^{* * *}$ & 0.801 & 0.007 & $0.142^{*}$ & 0.056 & 0.012 \\
\hline \multicolumn{2}{|l|}{ Households join unions $^{d}$} & $-1.338^{*}$ & 0.714 & 0.061 & $0.061^{* *}$ & 0.031 & 0.048 \\
\hline \multicolumn{2}{|c|}{ Households join the government ${ }^{d}$} & $-0.398^{\mathrm{NS}}$ & 0.751 & 0.596 & $-0.027^{\mathrm{NS}}$ & 0.055 & 0.622 \\
\hline \multicolumn{2}{|c|}{ Households join the Party ${ }^{d}$} & $1.629^{*}$ & 0.848 & 0.055 & $0.081^{* *}$ & 0.039 & 0.037 \\
\hline \multicolumn{2}{|l|}{ _cons } & $-10.830^{* * *}$ & 3.750 & 0.004 & & & \\
\hline
\end{tabular}

Note: Log-pseudolikelihood = -61.483; Number of obs = 218; Wald $\operatorname{chi}^{2}(25)=56.46 ; \mathrm{Prob}^{2} \mathrm{chi}^{2}=0.0003 ;$ Pseudo $\mathrm{R}^{2}=0.5507 ;$ bcs base variable; ${ }^{d}$ dummy variable (1=yes, $0=$ no); ${ }^{\log }$ The variable is logarithmic; ${ }^{* * *},{ }^{* *}$, and ${ }^{*}$, respectively, with statistical significance of $1 \%, 5 \%$, and $10 \%$; NS: No statistical significance. 
knowledge and skills in livelihood activities. Therefore, it will help households improve the probability of escaping poverty. Besides, participating in training courses and forest patrol teams also help households have the opportunity to exchange, share and learn experiences and knowledge from other households. At the same time, joining the forest patrol team, in addition to receiving direct support from forest protection programs, households also have the opportunity to harvest non-timber forest products on the way to patrol forests such as bamboo shoots, vegetables, etc.Since then, households participating in forest patrol groups have a $14.2 \%$ chance of escaping from poverty. Thus, the social relationship in the upland area, the study area is quite close and uniform among household groups. However, households with stronger social capital have also been shown as a factor to improve their income and poverty status.

Based on the estimated results, we also conducted an estimate of the accurate forecasting rate of the model. The results show that the ability to forecast correctly is nearly $89 \%$. In particular, the accurate forecasting rate of the model for the poor and non-poor households is $81,43 \%$ and $91,89 \%$, respectively. This correct forecasting rate is very high, which again confirms the appropriateness of the estimated model.

In short, as analyzed above, the livelihood capital of households is still limited, especially human and financial capital endowment. Households that are highly dependent on forests have weaker livelihood capital. Besides, the conditions for implementing this solution are quite favorable. The Government needs to pay attention to disadvantaged groups through the implementation of policies on education and training (improving human capital endowment), policies on credit support (improving financial capital ndowment), policies on supporting forest development, and paying forest environmental services (beneficiaries are people and communities that depend on forests). This latter solution is especially important for forest-dependent households, so this group should be identified as a priority when governments implement measures to improve the livelihood capital endowment of households.

\section{References}

Alary, V., Messad, S., Aboul-Naga, A. M., Osman, M.A., Daoud, I., Bonnet, P., Juanès, X.,\&Tourrand,J.F. (2014). Livelihood strategies and the role of livestock in the processes of adaptation to drought in the Coastal Zone of Western Desert (Egypt). Agricultural Systems, 128, 44-54. DOI: 10.1016/j. agsy.2014.03.008.

Babulo, B., Muys, B., Nega, F., Tollens, E., Nyssen, J., Deckers, J., \& Mathijs, E. (2008). Household livelihood strategies and forest dependence in the highlands of Tigray, Northern Ethiopia. Agricultural Systems, 98(2), 147-155. https://doi.org/10.1016/j. agsy.2008.06.001.
Bhandari, P. B. (2013). Rural livelihood change? Household capital, community resources and livelihood transition. Journal of Rural Studies, 32, 126-136. DOI: 10.1016/j.jrurstud.2013.05.001.

Carney, D., Drinkwater, M., Rusinow, T., Neefjes, K., Wanmali, S., Singh, N. (1999). Livelihoods approaches compared. A brief comparison of the livelihoods approaches of the UK Department for International Development (DFID), CARE, Oxfam and the United Nations Development Programme (UNDP) DFID.

Chambers, R. (1995). Poverty and livelihoods: whose reality counts? Environment and Urbanization, 7(1), 173-204. https:// doi.org/10.1177/095624789500700106.

Chambers, R.,\& Conway, G.R. (1992). Sustainable Rural Livelihoods: Practical Concepts for the 21st Century. IDS Discussion Paper, 296.

DFID. (1999). Sustainable livelihoods guidance sheets. London: The Department for International Development, 1-8.

Douxchamps, S., Ayantunde, A., Panyan, E.K., Ouattara, K., Kaboré, A., Karbo, N., \&Sawadogo, B. (2015). Agricultural water management and livelihoods in the crop-livestock systems of the Volta Basin. Water Resources and Rural Development, 6, 92-104. DOI: 10.1016/j.wrr.2014.10.001.

Ellis, F. (1998). Household strategies and rural livelihood diversification. The Journal of Development Studies, 35(1), 1-38. DOI: $10.1080 / 00220389808422553$.

Ellis, F., Kutengule, M.,\&Nyasulu, A. (2003). Livelihoods and rural poverty reduction in Malawi. World Development, 31(9), 1495-1510.

Fang, Y., Fan, J., Shen, M., \& Song, M. (2014). Sensitivity of livelihood strategy to livelihood capital in mountain areas: Empirical analysis based on different settlements in the upper reaches of the Minjiang River, China. Ecological Indicators, 38, 225-235. https://doi.org/10.1016/j.ecolind.2013.11.007.

Hussein, K. (2002). Livelihoods Approaches Compared: A MultiAgency Review of Current Practice. London. Department for International Development (DFID).

Kousar, R., Rais, S. I., Mansoor, A., Zaman, K., Shah, S. T. H.,\&Ejaz, S. (2019). The Impact of Foreign Remittances and Financial Development on Poverty and Income Inequality in Pakistan:Evidence from ARDL - Bounds Testing Approach. Journal of Asian Finance, Economics and Business, 6(1), 7181. http://doi.org/10.13106/jafeb.2019.vol6.no1.71.

Iyenger,S.,\& Shukla, N. (1999). Common Property Land Resources in India: Some Issues in Regeneration and Management. Ahmedabad, India: GIDR.

Mago,S. (2014). Microfinance and Poverty Alleviation: An Empirical Reflection. Journal of Asian Finance, Economics and Business, 1(2), 5-13.https://doi.org/10.13106/jafeb.2014. vol1.no2.5.

Nguyen, T. T., Do, T.L., Bühler, D., Hartje, R., \&Grote, U. (2015). Rural livelihoods and environmental resource dependence in Cambodia. Ecological Economics, 120, 282-295. https://doi. org/10.1016/j.ecolecon.2015.11.001. 
Pienkhuntod, A.,Amornbunchornvei, C.,\&Nantharath,P. (2020). Quantitative Analysis of Poverty Indicators: The Case of Khon Kaen Province, Thailand. Journal of Asian Finance, Economics and Business, 7(2), 131-141.https://doi.org/10.13106/ jafeb.2020.vol7.no2.131.

Reddy, S.R.C.,\& Chakravarty, S.P. (1999). Forest Dependence and Income Distribution in a Subsistence Economy: Evidence from India. World Development,27(7), 1141-1149. https://doi. org/10.1016/S0305-750X(99)00057-1.

Scoones, I. (1998). Sustainable rural livelihoods: A framework for analysis. IDS Working Paper, 72.
Senadjki, A., Mohd, S., Bahari, Z.,\&Hamat, A. F. C. (2017). Assets, Risks and Vulnerability to Poverty Traps: A Study of Northern Region of Malaysia. Journal of Asian Finance, Economics and Business, 4(4), 5-15. http://dx.doi.org/10.13106/jafeb.2017. vol4.no4.5.

Xu, D., Zhang, J., Rasul, G., Liu, S., Xie, F., Cao, M., \&Liu, E. (2015). Household Livelihood Strategies and Dependence on Agriculture in the Mountainous Settlements in the Three Gorges Reservoir Area, China. Sustainability, 7(5), 4850-4869. https://doi.org/10.3390/su7054850. 